Acta vet. scand. $1986,27,23-32$.

From the National Veterinary Institute, Oslo, the Department of Animal Husbandry and Genetics, Norwegian College of Veterinary Medicine, Oslo, and the Department of Animal Genetics and Breeding, Agricultural University of Norway, Ås.

\title{
IMPROVED AGAR PLATE ASSAYS OF BOVINE LYSOZYME AND HAEMOLYTIC COMPLEMENT ACTIVITY
}

\author{
By \\ Ø. Lie, M. Syed and H. Solbu
}

LIE, Ø., M. SYED and H. SOLBU: Improved agar plate assays of bovine lysozyme and haemolytic complement activity. Acta vet. scand. 1986, 27, 23-32. - Bovine serum and colostral whey samples were examined for lysozyme and haemolytic complement activity, employing agar plate techniques. The tests were carried out in agarose gel containing Micrococcus lysodeikticus (for lysozyme), and antibody sensitized rabbit erythrocytes (for complement), respectively. The confirmation of lysozyme (E.C.3.2.1.17) - dependent lysis has been presented elsewhere (Lie \& Syed 1986), while heat-inactivation and antibody to $\mathrm{C} 3$ were used in the present study to confirm that the haemolytic activity was attributable to the complement cascade. Repeatability and sensitivity of the described tests were found to be superior to those of photometric procedures. Staining and preservation techniques were developed which extended the applicability of the assay, as they made reading of results independent of time and resulted in the plates being very suitable for photography and storage.

cattle; non-specific immunity; assays; evaluation.

According to the literature, photometric methods have been predomonantly employed in studies on lysozyme activity (see Parry et al. 1965, Bratlid 1977, Lie 1980, Lie \& Solbu 1983), as well as on haemolytic complement (HC) levels (see Mayer 1961, Barta \& Barta 1972, Rurangirwa et al. 1980, Lie et al. 1983). Such methods are, however, cumbersome, laborious and suffer from inaccuracy and poor sensitivity. Therefore they have been progressively replaced by the far more reliable agar plate techniques, the so-called lysoplate assay for lysozyme (Osserman \& 
Lawlor 1966, Prieur \& Camara 1979), and HC assay in agarose plate for complement (see review by Lachmann \& Hobart 1979).

Another general disadvantage of photometric methods is that one has to continuously monitor the enzymatic action, or at least, the test has to be read shortly after the reaction has been accomplished. This is also to some extent the case for the conventional agar plate assays lacking built-in preservation or staining techniques.

This report describes two highly repeatable and sensitive agar plate methods each designed to assay one of the two lytic systems i.e. lysozyme and the complement cascade. An improvement that may be of particular interest is the successful staining and preservation technique developed for each plate.

\section{Source of material}

\section{MATERIAL AND METHODS}

Blood and colostrum samples were collected from cows kept at the research station of the Department of Animal Genetics and Breeding. Serum and colostral whey were prepared as described elsewhere (Lie et al. 1986).

\section{Assays}

L y s o p l a t e. Lysozyme activity was determined as described by Osserman \& Lawlor (1966) with some modification: $15 \mathrm{ml}$ of a $1 \%$ agarose gel in $0.07 \mathrm{~mol} / 1 \mathrm{NaH}_{2} \mathrm{PO}_{4} / \mathrm{Na}_{2} \mathrm{HPO}_{4}$ buffer, $\mathrm{pH}=6.2$, containing a photometrically determined amount of $50 \mu \mathrm{g} / \mathrm{ml}$ of Micrococcus lysodeikticus, was prepared on $10 \times 10$ cm defatted and agarose coated glass slides. Two-fold dilutions of hen egg white lysozyme (E.W.L.) ${ }^{*}$ with an original concentration of $1.6 \mu \mathrm{g} / \mathrm{ml}$ were employed as standards. The standards were stabilized in $1 \%$ bovine serum albumin (BSA) ${ }^{\star}$ dissolved in phosphate buffered saline (PBS). Sample wells of $3 \mathrm{~mm}$ in diameter were punched in 5 rows of 5 , and the lysozyme sources were applied in $9 \mu \mathrm{l}$ volumes. The plates were incubated at $38^{\circ} \mathrm{C}$ in a humidity chamber for $17 \mathrm{~h}$ (overnight), after which they were washed in distilled water for about $1 / 2 h$, pressed under filter paper, completely air dried and flame fixed. For staining, the following modified Gram procedure was used: The plates

\footnotetext{
* Sigma Chemical Company, USA.
} 
were placed in a $1.25 \%$ methylviolet solution for $1 \mathrm{~min}$ after which they were transferred to a lugol solution for $15 \mathrm{~s}$. They were then intensively destained with ethyl alcohol until stainless lysed zones appeared, and then left to dry. The diameters of the cleared zones were determined employing a so-called Measuring - Viewer* .

Within working levels of lysozyme, i.e. $1.6 \mu \mathrm{g} / \mathrm{ml}-0.1 \mu \mathrm{g} /$ $\mathrm{ml}$ the diameters of the zones were proportional to the $\log _{2}$ of the lysozyme activity.

To confirm that lysis was due to a true lysozyme (i.e. muramidase), serum and colostrum samples of different lysozyme activity were subjected to biochemical characterization in a parallel study (Lie \& Syed 1986).

H C a s a y in ag a r o s e p late. Total haemolytic capacity was determined by a plate method according to Lachmann \& Hobart (1979) with modification as follows: A photometrically standardized $1 \%$ suspension of rabbit red blood cells (RRBC) was prepared in $0.094 \mathrm{~mol} / \mathrm{l}$ veronal/sucrose-veronal buffer, $\mathrm{pH}=7.3, \mathrm{Ca}^{2+}$ and $\mathrm{Mg}^{2+}$ conc. $3 \times 10^{-4} \mathrm{~mol} / 1$ and $1 \times 10^{-3} \mathrm{~mol} / \mathrm{l}$, respectively (Rapp \& Borsos 1963, Barta \& Barta 1972, Lie et al. 1983). The RRBC were optimally sensitized with sheep antiserum (haemolysin) as described previously (Lie et al. 1983), mixed at $56^{\circ} \mathrm{C}$ with an equal volume $(8 \mathrm{ml})$ of $2 \%$ agarose in the same buffer, and poured into defatted and agarose-coated prewarmed $10 \times 10 \mathrm{~cm}$ glass slides. The final concentration of RRBC and haemolysin in the agarose was $0.25 \%$ and 1:600 respectively. Two-fold dilutions of a bovine serum sample with high haemolytic activity served as standards. Sample wells of $3 \mathrm{~mm}$ in diameter were punched in 6 rows of 6 and filled with a standardized volume, $9 \mu \mathrm{l}$, of haemolytic complement source (serum or whey). Samples and standards, stored at $-70^{\circ} \mathrm{C}$, were thawed once on ice, and plates were kept refrigerated during application. The plates were left at $4^{\circ} \mathrm{C}$ for $20 \mathrm{~h}$ (for diffusion) after which they were incubated at $38^{\circ} \mathrm{C}$ in a humidity chamber $\left(\mathrm{CO}_{2}\right.$-incubator $)$ for $90 \mathrm{~min}$ (to perform lysis). For preservation, the following procedure was developed: The plates were left to soak in a $4 \%$ phosphate buffered formaline solution for about $30 \mathrm{~min}$, after which they were pressed under filter paper and allowed to dry. The diameters of the lysed zones were measured as for the lyso-

* Behringwerke, W. Germany. 
zyme assay. Within working levels of haemolytic complement, the zone diameters were proportional to the log of the concentration, employing average serum activity as $100 \%$ (working range: $200 \%-6.25 \%$ of normal serum). To correct for possible influence of naturally occurring haemolysins, absorption with RRBC was performed on samples with different activity as decribed by Lie et al. (1983). To confirm that the lysis was elicited by the complement cascade, some representative samples were subjected to heat-inactivation $\left(56^{\circ} \mathrm{C}\right)$ and some to preincubation with rabbit antibody to bovine $\mathrm{C} 3$ component ${ }^{\star}$ at $38^{\circ} \mathrm{C}$ for $1 \mathrm{~h}$ before plating. Some samples were also subjected to double diffusion against anti C3 to confirm lysis-zone inhibition.

\section{Statistical methods}

A one-way analysis of variance was used to estimate the intra class correlation or the repeatability $(t)$ of the described assays. To estimate the standard error of the estimated $t$, the method described by Becker (1967) was used.

\section{RESULTS AND DISCUSSION}

\section{Evaluation of the assays}

Sensitivity. Lysozyme activity could be detected at an average dilution of 1 in approx. 800 corresponding to levels of about $2 \times 10^{-3} \mu \mathrm{g}$ E.W.L. per ml. This is partly reflected in Fig. 1, where lysis can be seen at 1 in 512 and is a 20 fold improvement over the photometric procedure which showed a sensitivity of about $4 \times 10^{-2} \mu \mathrm{g} / \mathrm{ml}$ (Lie \& Solbu 1983). If desired, the sensitivity can be further improved by multiple application or by employing lysoracket (Virella 1977, Lie \& Syed 1986).

Haemolytic activity was detected at a dilution of 1:256 on average, or about $0.4 \%$ normal serum corresponding to about $0.036 \mu$ l of neat serum (see Fig. 2). This is about 20-30 times the sensitivity achieved by the photometric procedure. An amount of whey of $220 \mu \mathrm{l}$ had to be employed in the photometric test to detect the lowest colostral haemolytic activity (unpublished data), whereas $9 \mu \mathrm{l}$ whey was sufficient for the plate assay in this study (see Fig. 2).

\footnotetext{
* Cappel Laboratories, USA.
} 


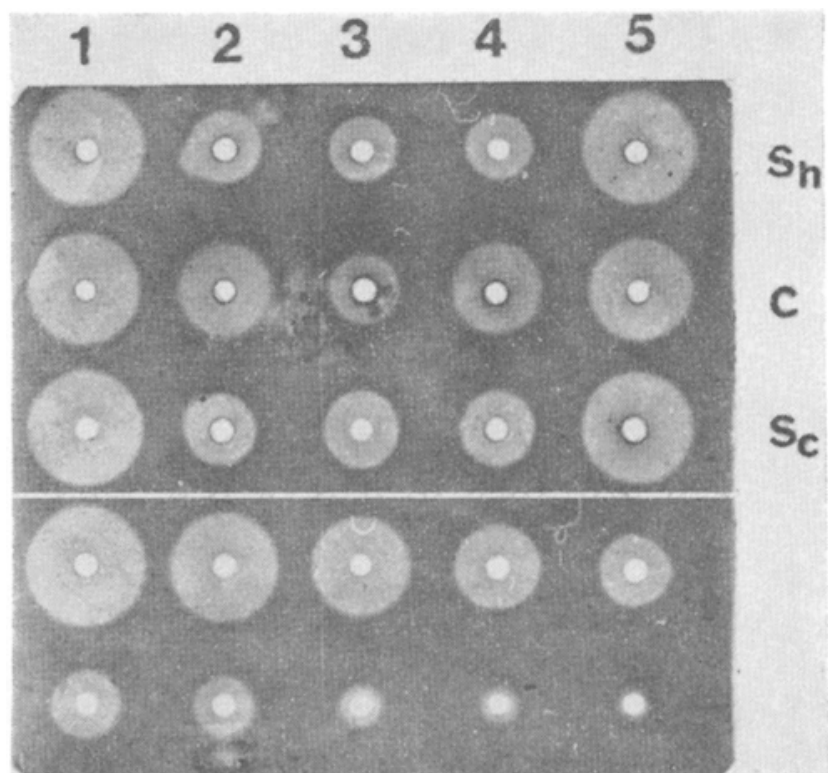

F i g u r 1. Lysosyme assay in agarose gel containing Micrococcus lysodeikticus.

Upper part: Serum 1 year prior to parturition $\left(S_{h}\right)$, Colostrum (C) and serum $\left(\mathrm{S}_{\mathrm{c}}\right)$ at the time of calving for 5 different animals of which no. 1 and no. 5 are high level individuals.

Lower part:

Two-fold dilutions of hen egg white lysozyme (E.W.L.) standard with an initial concentration of $1.6 \mu \mathrm{g} / \mathrm{ml}$.

Repeatability and specificity. Zone diameters of different doubling dilutions of the standards ( 5 from E.W.L., 5 from a bovine serum standard for lysozyme, and 6 from a bovine serum standard for haemolytic complement) as well as a series of unknown samples, were collected from 20 plates in each assay. Variation between and within dilution, as well as between and within unknown samples, and the corresponding repeatability $(t)$, was estimated for both assays. Findings were $0.98 \pm 0.03$ and $0.95 \pm 0.03$ for lysozyme and complement, respectively. The superiority over photometric procedures (Lie \& Solbu 1983, Lie et al. 1983) is probably due to the many volumetric errors eliminated with the plate methods. The dilution step is automatically undertaken by the agar diffusion and is very reproducible. Moreover, the greater test capacity eliminates day to day variation. 


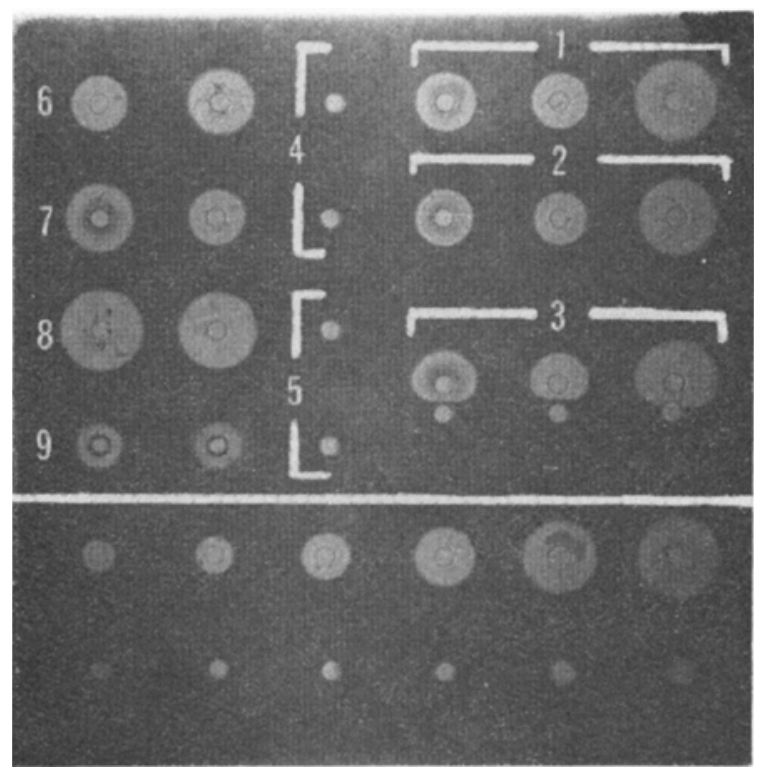

F i g u r e 2. Haemolytic complement assay in agarose gel containing haemolysin-sensitized rabbit erythrocytes.

Upper part:

1. Normal serum from 3 different cows.

2. Sera from the same animals absorbed for natural haemolysins.

3. Sera from the same animals subjected to double diffusion against specific rabbit anti bovine C3.

4. Heat inactivated $\left(56^{\circ} \mathrm{C}\right.$ for $\left.1 / 2 \mathrm{~h}\right)$ serum and colostrum.

5. Serum and colostrum preincubated $\left(1 \mathrm{~h}\right.$ at $\left.37^{\circ} \mathrm{C}\right)$ with anti C3 before application.

$6,7,8$. Serum from heifers, primiparous cows and multiparous cows, respectively.

9. Colostrum from primiparous cows.

Lower part:

Two-fold dilutions of a bovine serum standard (high activity serum).

That lysozyme activity is constant within the same animal is clearly illustrated in Fig. 1, upper part. This is a reflection of the strong genetic influence and simple inheritance of this trait, i.e. either high or low activity (Lie \& Solbu 1983). At the same time, it shows the reliability of this method in easily detecting this pattern, when may be overlooked when employing mehods with poor repeatability and sensitivity.

A parallel study (Lie \& Syed 1986) has confirmed that the lytic power against M. lysodeikticus assayed in the present study 
exhibits properties which are in accordance with those defined for a lysozyme (E.C.3.2.1.17), i.e. 1.4- $\beta-\mathrm{N}$ acetylmuramidase cleaving the glycosidic bond between $\mathrm{C}-1$ of $\mathrm{N}$-acetylmuramic acid and C-4 of N-acetylglucosamine (see also Jollès \& Jollès 1984).

Confirmation that the haemolytic activity studied is attributable to the complement cascade can be clearly seen from Fig. 2. Parts 3 and 5 show the inhibition of specific antibody to complement component $\mathrm{C} 3$ of cattle, while part 4 shows the heat sensitivity of the system. Parts 1 and 2 are controls for the influence of naturally occurring cattle antibody to RRBC. A slight reduction in HC titer was observed after absorption (part 2) though there was no rearrangement between animals.

Parts 6, 7 and 8 show the effect of age on HC levels, the older cows having the highest levels, whereas part 9 indicates the very low HC of colostrum (about 5 to $10 \%$ of normal serum).

The $50 \%$ lysis end point in photometric procedures may probably be a more relevant measure of haemolytic capacity. This is especially the case when considering the possible limiting effect of certain C-factors with low rate agar diffusion. However, the prediffusion step before the lysis in the plate assay may have eliminated this problem, since with tube and plate methods running in parallel, a correlation of 0.90 was found.

Also with regard to lysozyme, one should be aware that different methods might be measuring different things (i.e. total lytic capacity or enzyme concentration). For instance, two individuals, one possessing high enzyme concentration and low specific activity and the other having the opposite profile, might appear to have the same lytic capacity in a tube assay, whilst in the plate assay, the one with the high concentration will be the superior. However, when comparing the two lysozyme assays, the overall correlation was high $(r>0.90)$. This indicates that the difference in lysozyme activity between individuals is probably attributable to different enzyme concentrations rather than to different specific activities of different types of enzymes (Lie \& Syed 1986).

The above correlations between tube and plate assays, both for the HC and lysozyme, might be even higher with improved repeatability of the tube assays. 
Economy and capacity. The amount of serum needed for photometric assays was $200 \mu \mathrm{l}$ and $60 \mu \mathrm{l}$ for lysozyme and haemolytic complement, respectively (1200 $\mu \mathrm{l}$ whey was needed for photometric H.C. assay), whereas $9 \mu \mathrm{l}$ was sufficient for both plate methods. This is mainly due to the reagentexpensive dilution procedures of photometric methods. Taking also into account the superior sensitivity, the plate methods could be regarded as being more than one hundred times more efficient. In addition come the test capacity (10-20 times more samples per day) and the flexibility in reading the plates (nonrestrictive in time). This means that the plate method is a more rational choice for screening purposes than conventional (nonautomated) photometric procedures.

Applicability. One possible drawback of the plate methods is that they are practically impossible to automate. Optimalized arrangements of modern photometric equipment such as microtiter-plate readers might thus compete with the agar plate assays with regard to mass analysis of routine samples, provided sufficient controls are included. However, we have found the microtiter test to be quite labour intensive (especially for complement), and much less reliable than the agar plate test (especially for lysozyme). The high purchase and running costs of the equipment required for automated photometric methods is also a disadvantage to be taken into account.

The described agar plate methods have proved to be rational and inexpensive tools with a wide range of possible applications. In particular, the methods seem convenient for screening large numbers of samples in epidemiological, clinical or genetical studies. Also when dealing with purification procedures (chromatography, isoelectric focusing etc.), large numbers of fractions can be dealt with readily, due to the high capacity of the test. The methods also seem convenient for qualitative studies (components, types of enzymes, polymorphisms etc.). In such cases, the plates may be employed as detector tools such as overlayers after different electrophoretical procedures. In this context, the staining and preservation techniques may also be an extra benefit, extending the practical applicability of the plates and making them available for almost unlimited storage. 


\section{REFERENCES}

Barta, O. \& V. Barta: Haemolytic assay of bovine serum complement. J. immun. Methods 1972, 1, 363-374.

Becker, W. A.: Manual of Procedures in Quantitative Genetics. Washington State University Press, Pullman, Washington 1967, $130 \mathrm{pp}$.

Bratlid, D.: A simple procedure for determination of bacteriolytic activity in biological fluids. Acta path. microbiol. scand. 1977, $85,17-20$.

Jollès, P. \& J. Jollès: What's new in lysozyme research? Always a model system, today as yesterday. Mol. cell. Biochem. 1984, 63, $165-189$.

Lachmann, P. J. \& M. J. Hobart: Complement technology. In Handbook of Experimental Immunology. Vol. 1 Immunochemistry. Ed. D. M. Weir. Blackwell Scientific Publications, Oxford, London, Edinburgh, Melbourne 1979, p. 5A.1—5A.23.

Lie, Ø.: Genetic variation in serum lysozyme activity in cattle. Acta vet. scand. $1980,21,448-450$.

Lie, $\emptyset$. \& H. Solbu: Evidence for a major gene regulating serum lysozyme activity in cattle. Z. Tierzucht. Züchtbiol. 1983, 100, 134 -138.

Lie, Ø., M. Syed \& H. Solbu: The genetic influence on serum haemolytic complement levels in cattle. Anim. Blood Grps. biochem. Genet. 1983, 14, 51-57.

Lie, Ø., H. Solbu \& M. Syed: A genetic association between bovine serum and colostrum lysozyme levels. Anim. Genet. 1986, 17, $39-45$.

Lie, Ø.\& M. Syed: Some properties of the lysozymes in serum and colostrum from cows with high and low lytic power against Micrococcus lysodeikticus. Anim. Genet. 1986, 17, 47-59.

Mayer, M. M.: Complement and complement fixation. In Experimental Immunochemistry, E. A. Kabat \& M. M. Mayer (eds.), Charles Thomas, Springfield, Illinois 1961, 133-240.

Osserman, E. F. \& D. P. Lawlor: Serum and urinary lysozyme (muraminidase) in monocytic and monomyelocytic leukemia. J. exp. Med. 1966, 124, 921-951.

Parry, R. M., R. C. Chandan \& K. M. Shahani: A rapid and sensitive assay of muramidase. Proc. Soc. exp. Biol. (N. Y.) 1965, 119, $384-386$.

Prieur, D. J. \& V. M. Camara: Inheritance of lysozyme deficiency in rabbits. J. Heredity 1979, 70, 181-184.

Rapp, H. J. \& T. Borsos: Effects of low ionic strength on immune haemolysis. J. Immunol. 1963, 91, 826-832.

Rurangirwa, F. R., H. Tabel, G. Losos \& I. R. Tizard: Hemolytic complement and C3 levels in Zebu Cattle infected with Trypanosoma congolense and Trypanosoma vivax and the effect of trypanocidal treatment. Infec. Immun. 1980, 27, 832-836.

Virella, G.: Electrophoresis of lysozyme into Micrococcus-containing agarose gel: Quantitative and analytical applications. Clin. chim. Acta 1977, 75, 107-115. 


\section{SAMMENDRAG}

Forbedrede agarplatemetoder til bestemmelse av bovint lysozym og hemolytisk complement aktivitet.

Bovint serum og kolostrum ble unders $\varnothing$ kt for lysozym- og hemolytisk complement-aktivitet ved hjelp av lysoplateteknikker. Testene ble utf $\varnothing$ rt i agaorse-gel inneholdende Micrococcus lysodeikticus (for lysozym) og antistoff - sensiterte kaninerytrocytter (for complement). Bekreftelsen på lysozym - spesifikk lysis er utført ved biokjemiske analyser $\mathrm{i}$ et annet studium (Lie et al. 1986) mens varmeinaktivering og spesifikke anti-C3-antistoffer ble anvendt $i$ dette arbeidet for å bekrefte complement-avhengig hemolyse. Reproduserbarhet, sensitivitet og kapasitet på de beskrevne platemetoder ble funnet å være betydelig bedre enn for fotometriske tester. Dessuten ble fargings-/preserveringsteknikker utviklet, noe som $\phi$ ker anvendbarheten av testene $\mathrm{i}$ det avlesninger blir tidsuavhengige og platene velegnet for fotografering og lagring.

\section{(Received October 7, 1985).}

Reprints may be requested from: $\emptyset$. Lie, the National Veterinary Institute, P. O. Box 8156, Dep., N-0033 Oslo 1, Norway. 